\title{
THE MILLENIAL GENERATION, HADITH MEMES, AND IDENTITY POLITICS: The New Face of Political Contestation in Contemporary Indonesia
}

\author{
Ali Imron \\ Universitas Islam Negeri Sunan Kalijaga Yogyakarta, Indonesia \\ E-mail: bapakeaqil@gmail.com
}

\begin{abstract}
Since society has been encountering the advanced technology of smartphones, the internet has become the most crowded channel as well as a noisy stage for disputes on religious issues. The preceding disagreement on hadith that manifested in thick books has now transformed into pictures or, I should call, hadith memes. Using the theory of Richard Dawkins, this article maps the forms of disputes involving hadith that are represented by memes. This qualitative research places those memes as the material object, while the messages provided by the hadith as the formal object. The reason behind the use of Dawkins' theory is that those memes do not explicitly contain messages alone, but also sharp identity politics, criticism, contestation, satire, cynicism. As a result, this research maps hadith memes that are distributed on the internet into four categories. They are formed with straightforward messages and satires, containing ideological ideas of several religious groups in order to maintain their existence as well as win the contestation for power.
\end{abstract}

Sejak masyarakat mengalami booming handphone, media internet menjadi salah satu kanal yang paling bising sekaligus beralih fungsi jadi panggung perdebatan isu keagamaan yang berisik. Bila dulu pergulatan pemikiran hadis mewujud dalam bentuk buku-buku tebal, kini berubah wujud dalam 
gambar-gambar meme hadis. Dengan teori Richard Dawkins, tulisan ini memetakan secara tajam bentuk-bentuk pergulatan pemikiran hadis yang bersembunyi di balik gambar-gambar meme tersebut. Riset kualitatif ini menempatkan gambar-gambar meme hadis sebagai objek material, sedangkan pesan-pesan hadis yang disampaikannya sebagai objek formal. Alasan digunakannya teori Dawkins ialah karena meme-meme tersebut tidak hanya memuat pesan-pesan eksplisit, tapi juga identitas, kritisisme, kontestasi, satir, dan sinisme yang tajam. Hasilnya, penelitian ini berhasil memetakan meme-meme hadis yang tersebar di internet menjadi empat jenis kelompok besar. Meme-meme tersebut diisi dengan bahasa lugas maupun bahasa satire. Keempat jenis meme ini disarati dengan pesan-pesan ideologis kelompok-kelompok keislaman di mana masing-masing mereka memakainya sebagai alat untuk berkontestasi dan menegaskan identitas demi mempertahankan eksistensi dan memenangi perebutan kekuasaan. Karena hanya membatasi diri pada meme-meme hadis, penelitian ini belum mengcover meme-meme yang berisi ayat-ayat al-Qur'an, padahal ia juga marak beredar di Internet, sehingga perlu juga diteliti untuk melengkapi kajian ini.

Keywords: hadith; identity politics; Indonesia; memes; Millenials

Received: October 29, 2018; Accepted: December 9, 2019

\section{Introduction}

Even though this research is concerned with hadith, the term generation in this study refers to humanities sciences, especially culture studies, instead of to hadith sciences where the term tabaqa is widely recognized with more or less the same signification. That is because the undeniable shortfall of the literature; it is unlikely to define millennials generation referring to the works of tabaqât developed in hadith sciences.

Generation is a social construction referring to a group of people with the relatively same age and historical experiences. Manheim explains that a member of a generation is who has a similar year of birth in the range of twenty-year period and live in a similar socio-historical dimension. This definition is further developed by Kupperschmidt, who suggests that generation is a group of individuals who identify themselves based on the similarity of the year of birth, age, location, and events in their life, that have a significant influence in a particular phase of history (Putra 2016, 124). 
From this definition, several scholars divide world societies into several generations. Topscott, cited from Putra, divides the current world citizens into three generations, while Howe and Strauss, Lancaster and Lancaster and Stillman, and Martin Tulgan divide people into four generations, whereas Oblinger and Oblinger provides five generations. These scholars divide the generations based on the year of birth. The following is the table of the division of the generations from these scholars.

Table 1

Several groupings of generations (Putra 2016)

\begin{tabular}{|c|c|c|c|c|c|}
\hline Sumber & & & Label & & \\
\hline Tapscott (1998) & - & $\begin{array}{c}\text { Baby Boom } \\
\text { Generation } \\
(1946-1964)\end{array}$ & $\begin{array}{c}\text { Generation X } \\
(1965-1975)\end{array}$ & $\begin{array}{c}\text { Digital } \\
\text { Generation } \\
(1976-2000)\end{array}$ & - \\
\hline $\begin{array}{l}\text { Howe \& Strauss } \\
\quad(2000)\end{array}$ & $\begin{array}{c}\text { Silent } \\
\text { Generation } \\
(1925-1943)\end{array}$ & $\begin{array}{c}\text { Boom } \\
\text { Generation } \\
(1943-1960)\end{array}$ & $\begin{array}{l}13^{\text {th }} \text { Generation } \\
(1961-1981)\end{array}$ & $\begin{array}{c}\text { Millenial } \\
\text { Generation } \\
(1982-2000)\end{array}$ & - \\
\hline $\begin{array}{l}\text { Zemke et al } \\
(2000)\end{array}$ & $\begin{array}{c}\text { Veterans } \\
(1922-1943)\end{array}$ & $\begin{array}{c}\text { Baby Boomers } \\
(1943-1960)\end{array}$ & $\begin{array}{l}\text { Gen-Xers } \\
(1960-1980)\end{array}$ & $\begin{array}{c}\text { Nexters } \\
(1980-1999)\end{array}$ & \\
\hline $\begin{array}{l}\text { Lancaster \& Stillman } \\
\qquad(2002)\end{array}$ & $\begin{array}{l}\text { Traditionalist } \\
(1900-1945)\end{array}$ & $\begin{array}{c}\text { Baby Boomers } \\
(1946-1964)\end{array}$ & $\begin{array}{c}\text { Generation Xers } \\
(1965-1980)\end{array}$ & $\begin{array}{r}\text { Generation Y } \\
(1981-1999)\end{array}$ & \\
\hline $\begin{array}{l}\text { Martin \& Tulgan } \\
\qquad(2002)\end{array}$ & $\begin{array}{c}\text { Silent } \\
\text { Generation } \\
(1925-1942)\end{array}$ & $\begin{array}{c}\text { Baby Boomers } \\
(1946-1964)\end{array}$ & $\begin{array}{c}\text { Generation X } \\
(1965-1977)\end{array}$ & $\begin{array}{l}\text { Millenials } \\
(1978-2000)\end{array}$ & \\
\hline $\begin{array}{c}\text { Oblinger \& Oblinger } \\
(2005)\end{array}$ & $\begin{array}{l}\text { Matures } \\
(<1946) \\
\end{array}$ & $\begin{array}{c}\text { Baby Boomers } \\
(1947-1964)\end{array}$ & $\begin{array}{c}\text { Generation Xers } \\
(1965-1980) \\
\end{array}$ & $\begin{array}{c}\text { Gen-Y/NetGen } \\
(1981-1995) \\
\end{array}$ & $\begin{array}{c}\text { Post Millenials } \\
\text { (1995-present }\end{array}$ \\
\hline
\end{tabular}

This table shows that that the millennial generation is those who were born from the 1970s up to the 2000s, referring to Martin and Tulgan, or Y generation (Gen-Y, also known as NetGen; the acronym of Internet Generation), referring to the categorisation of Oblinger and Oblinger. In the category of Oblinger, $\mathrm{Y} / \mathrm{NetGen}$ is considered equal to Post-Millennial, because they are the generations born and raised unseparated from internet technology.

Millennial generation likes speed, instantness, and practicality that is supported by internet technology; they dislike complication, pleonastical, and boring things. The primary characterisations of this generation in its relation to technology are as follows: (1) Instant communication, that this generation live in the real-time tendency and always look for convenient 
and direct communication; (2) network development, that is the development of a system making them interconnected each other for the potential collaboration; (3) Gadget-powered connection, that this generation loves gadget that provides them with internet connection, such as cellphone, game, laptop/netbook, etc. In sum, the adoption of technology of this generation has developed much more than it had been in the previous generation (Putra 2016, 125).

Muslims undeniably encounter this situation. Speaking of Islam, the religious discourse is always a subject of discussion, either about the Qur'an, hadith, fiqh, or politic. This leads to disputes and contestation on religious discourses by several Islamic groups. We heard of disputes between several groups of Islam, such as between Sunnî-Shî' $\hat{1}$, traditionalist-modernist, textualist-contextualist, etc. that manifested in scholarly works such as books, articles, magazines, and the likes. Currently, the disputes occur in a new medium, namely memes.

The occurrence of memes is an exciting subject of scholarly attention from various disciplines. The spectrum of the use of meme is pretty much broad, sparking a serious inquiry from researchers, started from economy-business, politics, law, linguistics, communication, and religion is no exception. The use of meme in business, for example, is the subject of study by Jurvetson, Williams, Wu and Ardley, Murrey et al., and so on. Those scholars analyse the influence of memes in product marketing (Jurvetson 2000; Williams 2000; Wu and Aerdley 2007; Murray, Manrai and Manrai 2014).

The inquiry about memes also occurs in studies of law and ethics. Those from this disciplines who are interested in memes are Ekstrand and Silver, Kien, Johnson, and Gervais and Hyndman (Kien 2013; Ekstrand and Silver 2014; Johnson 2013; Gervais and Hyndman 2012). Whereas in communication, the meme is the subject of study by Siregar et al., Sudarsono, Untari, Fatonah et al., and so on (Siregar, Gurning, and Santoso 2018; Sudarsono 2017; Untari 2017; Fatonah, Sumarti, and Riadi 2017).

The use of meme in politics has also attracted scholarly inquires of several scholars, such as its use as a medium to voice political aspiration (Hristova 2014; Bebić, et al. 2018; Morimoto 2018; Kulkarni 2017). In the case of an election, the use of memes drastically increases, such as what happened to the presidential election of the United States (Heiskanen 2017; Ross and Rivers 2017; Moody-Ramirez and Church 2019). Not only 
in the United States, memes play significant role as well in the Middle East Arab Spring in Egypt, Tunis, Aljazair, Maroco, Yaman, etc (Harlow 2013; Howard et al. 2011; Al Zidjaly 2017; Howard and Hussain 2013; Owais 2011).

The issue of meme also infiltrates religious studies, especially Islam. A ton of memes that are distributed on the internet contains Islamic messages, either the universal religious advice or the emphasis of the political identity of a particular group as well as an attack to the competing groups. This phenomenon is the subject of discussion of Sulthani, Alamsyah, Rozaq, Nindya, Mothohhirin, and Miski (Sulthani 2016; Alamsyah 2018; Rozaq 2019; Nindya 2019; Muthohirin 2015; Miski 2017).

Amongst those studies, one which has similarity with this study is that of Miski, entitled "Fenomena Meme Hadis Celana Cingkrang dalam Media Sosial." Nevertheless, his issue is very specific, dealing only with memes on celana cingkrang (capri pants; shorter pants that go above the ankle), without mapping the use of that memes on the internet even further. Above all, unlike all of those studies, this article provides the schematic picture of how the memes are used on the internet as well as captures ideological disputes and political identity contestation behind the distribution of those memes on the internet in contemporary Indonesia.

This library research makes memes containing the prophetic tradition distributed on internet as its material object. The data are compiled from the internet, and are further classified into categories before analysed in a qualitative framework using content analysis method; the result of the research would be provided in the descriptive-analytical method. Richard Dawkins' theory is employed in this research, not rigidly, but with a modification in several areas.

\section{Theory of Memes}

According to research by Juditha in 2015 , there is no equivalent word for meme in Indonesian language (Juditha 2015, 105). Indonesians tend to pronounce it as me-me, instead of meem. However, lately, the online Kamus Besar Bahasa Indonesia (KBBI, The Main Dictionary of Indonesian Language) defines meme as follow:

1. A noun referring to an idea, attitude, or style spread from one person to others in a particular culture; 
2. The preview of pictures from the television show, film, or others, or selfmade pictures modified with additional words or sentences in the intention of creating jokes of entertainment.

The word meme was introduced by Richard Dawkins, a Zoologist from Oxford University, in his book, The Selfish Gene. The origin of the word is a Greek word, mimesis, which means replicator. Dawkins defines meme as the smallest unit of cultural transmission that has the capability of doubling up itself. Dawkins provides an analogy with the gene in biology. He suggests:

"We need a name for the new replicator, a noun that conveys the idea of a unit of cultural transmission, or a unit of imitation. 'Mimeme' comes from a suitable Greek root, but I want a monosyllable that sounds a bit like 'gene'. I hope my classicist friends will forgive me if I abbreviate mimeme to meme* If it is any consolation, it could alternatively be thought of as being related to 'memory', or to the French word meme. It should be pronounced to rhyme with "cream" (Dawkins 1976, 192).

As mentioned above, the theory of meme from Dawkins draws inspiration from evolution theory in biology. This theory explains evolution as a mechanism of maintaining the existence of an organism that takes form as continually changing. Before Dawkins, changes in evolution was understood to happen in individual level of species. The Dawkin's theory of selfish gene criticises this assumption, suggesting that evolution happens more in the level of genes or DNA.

If the gene (in biology) duplicates itself in a gene pool by jumping from one parent to its offspring through the sperm and ovum, meme duplicates itself through a meme pool, jumping from one to others through imitation. Furthermore, Dawkins explains that meme is a gene of culture (idea, thought, attitude, etc.) that spreads out through imitation, such as songs, jargons, fashion style, and even the architectural formation (Wijayanto 2013).

The meme on the internet, particularly in social media, is another form, if not development, of Dawkins' idea about popular culture, especially internet. In this context, a particular idea, concept, or thought spreads in a particular pool after having encountered imitation process that goes viral as a visual material, from a brain of a person to others with the help of computer or smartphone. 
The visual memes on the internet vary in format; some are still images, while others are GIF animation or even longer videos. Nevertheless, the memes distributed as images significantly outnumber other formats, most probably, for its simplicity, despite its low quality, as the result of their creator's main objective are delivering the message. Typically, this kind of meme is formed with texts and pictures, but there are a lot of them that contain merely text using various kinds of fonts and size.

A meme is produced through the process of replication and modification of visual images that are easily accessed from google. A creator of meme transfers his idea to the meme using texts, adding or reducing images through a simple digital process, depending on the intention of the meme. After the replication process, the meme will further be spread out through features provided by social media, such as share, retweet, or repost. This technology enables creators of memes to produce more and more new memes so that the older ones sooner or later are replaced with the new ones, with only a few of them that are capable of survival.

Within the evolution in the biological sense, the weakest genes would be left out before further wholly disappear; only the strong genes that are able to survive. Dawkins calls the strong genes as the selfish genes that always want to appear at the surface to show their existence. For that matter, they are always in constant effort to strengthen themselves. In contrary, the unselfish genes tend to hide, does not appear at the surface, before eventually sink, disappear, and extinct. This also happens in culture, especially meme culture. The strong memes are capable of survival, while the weak memes would very soon disappear, drowned by changes, and are eventually replaced by new strong memes. In this context, the principle of survival of the fittest is equally relevant.

The word selfish is used by Dawkins to explain that a gene has the tendency to be egoistic, in the sense that it considers itself with upmost of importance in order to survive and replicate. Nevertheless, this does not mean that an egoistic gene thinks only of itself alone. There is also a kinship factor, by which genes of a common group would strive to stand with and defend its familial gene, in the sense that all of the individuals in a group that posses the same genes would work together to maintain their existence. A gene parent is eager to sacrifice in the interest of its child, not only for its social altruism, but also for the motivation of genetical and the egoism of the group, making it behave to protect the gene of its kind found in the body of its children to make possible the transmission of the genes is 
preserved. Despite this naturally happens, this does mean that the genes of the offsprings order the parents to do so. What happens, instead, is that if genes of offspring can influence the behaviour of the gene of parents, the former would have a better chance of further replication (Hukmi n.d.).

At this point, as genes in the evolution are in constant competition against each other in order to survive, memes on the internet are also in the same contestation to maintain the existence of the cultural system of their creators. Because memes contain messages from their creators, they are not the beautiful images yet empty from ideological messages of a particular cultural system. Instead, they are the tools of political identity, the weapons of cultural contestation against competing groups. The contestation between memes represents the contestation of identity politics of the competing groups. The competition in this internet sphere sometimes is brutal, filled with anonymous rhetoric (Jarvis 2014, 326-49). Nevertheless, the creator of the memes are not by any means fully unidentifiable; the content of the memes gives a clue about who attacks who.

\section{The General Map of Hadith Memes}

Seen from the materials they consist of, the memes containing hadith material can be divided into several groups. First, the complete meme, that is which provides a complete text of the prophetic tradition, both its Arabic and its translation in the Indonesian language. This kind of memes enables the researcher to conduct takhrîj before eventually know the quality of the hadith quoted in the meme in a meme, whether it is sahîh, hasan, or da îf (see picture 1 below).

Second, the memes which provide only the translation of the hadith without its Arabic text. This category raised a particular problem with regards to tracing the hadith it provides, especially when a meme provides hadith outside of the nine canonical hadith books (al-kutub al-tis 'ah), such as al-Mustadrak al-Hâkim, Mu jam al-Tabrânî, and so on. For the hadiths from al-kutub al-tis 'ah, it is relatively easier to conduct takhrîj, thanks to the application of Lidwa (see picture 2 below). Third, the memes that contain what the creators consider to be the central message of the hadith. On the other words, this meme does not provide the Arabic text, nor the translation of a particular hadith, but rather the summary of its message only. In many instances, a particular meme of the third category compiles the message of several hadiths (see picture 3 below). 
Fourth, the memes that do not provide the text of the hadith, nor its translation, but only the quotes from particular religious authorities, either individual figures or institutions. The statements of authority are typically recognized widely by the public and considered to have a sort of legitimacy. Memes in this category typically provide the picture of particular figures along with quotes from him/her (see picture 4).

Picture 1

(http://nuroneblog.blogspot.com)

\section{Ka'ab bin Malikice berkata,}

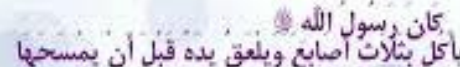

"Dahulu Rasulullahes"

makan dengan tiga jaRj

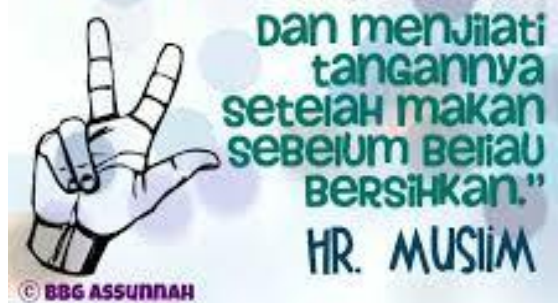

Picture 3

(https://www.toopics.com)

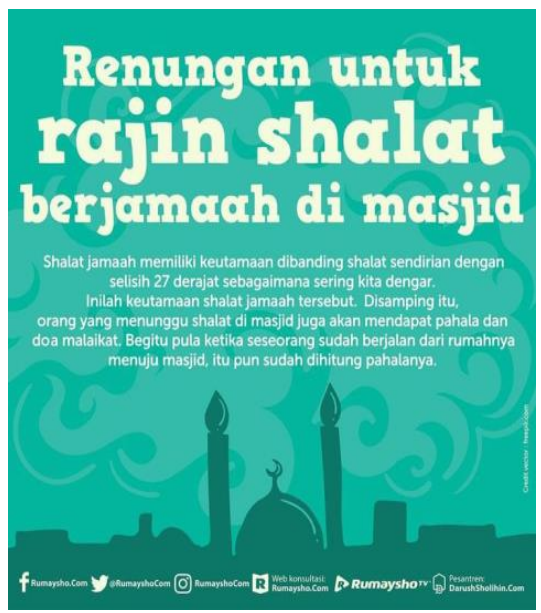

Picture 2

(http://ikhlasmedia.blogspot.com)

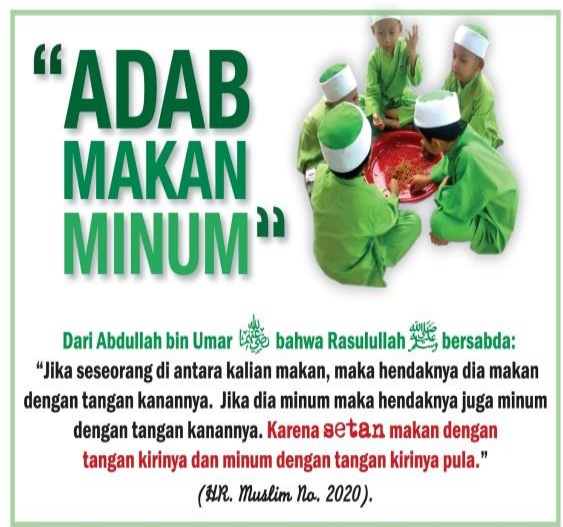

Picture 4

(https://www.dutaislam.com)

MAULID NAB| ADALAH BIDAH

TIDAK ADA DALAM ALQURAN \& HADITS SAHABAT TIDAK PERNAH MELAKUKAN 
In picture 1 and 2, the source of the hadith in the memes can be easily recognized, in which case is from Muslim; the Arabic text of the hadith and its translation refer to Sahîh Muslim. That is not the case, however for the third picture. The meme does not indicate its source, nor does it provide the text of the hadith or its translation. However, the text that is written in smaller font essentially delivers the main messages of several hadiths. It says as follows:

"Shalat jamaah memiliki keutamaan dibanding shalat sendirian dengan selisih 27 derajat sebagaimana sering kita dengar. Inilah keutamaan shalat berjamaah tersebut. Di samping itu, orang yang menunggu shalat di masjid juga akan mdenapat pahala dan doa malaikat. Begitu pula ketika seseorang sudah berjalan dari rumahnya menuju masjid, itu pun sudah dihitung pahalanya."

"Jama'a prayer has eminence compared to alone prayer as much as 27 levels as we have heard of. This is the eminence of the jama'a prayer. Besides, one who waits for prayer in a mosque will also obtain reward and prayer from the angel. Likewise, when one walks from his home to the mosque, he obtains rewards."

Picture 4 does not contain the hadith text whatsoever, either in Arabic or in Indonesian. It only provides the photograph of the famous preacher, Zakir Naik, with a quotation, as if the figure in the picture says the sentences provided by the meme.

\section{Contestation of Identity Politics in Hadith Memes}

Donald L Morowitz, cited from Haboddin, defines identity politics as a sharp demarcating line to separate accepted communities (considered as the friend) from unaccepted ones (not considered friend, or even more considered enemy). The main point of identity politics is the politic of differentiation for the interest of obtaining advantage or victory. The act of consociating people in order to accept or reject other parties is based on similarities and differences in races, ethnicities, religions, social groups, and so on (Haboddin 2012).

As mentioned earlier, Islamic history shows the occurrence of various groups with distinctive ways of understanding and traditions. Early history displays the presence of Mu'tazilah, Shî'ah, Jabbariyyah, Qadariyyah, Karimitiyyah, and so on. The disputes between those groups eventually become the legacy of Islamic history that is inherited throughout the generations. In the contemporary history, a new way of classifying the 
developing trends in Islamic societies comes up, leading to the emergence of the traditionalist, textualist, jihadist, modernist, secularist, pluralist, and so on. Each trend feels to have a distinctive identity from others.

In the past, the disputes between those groups manifested not only in harsh disagreement but also in repressive conduct of rulers, such as the mihna during the lifetime of Imam Hanafî and Imam Ahmad ibn Hanbal. The records of these disagreements are preserved in voluminous literature stored in various libraries. Ibn Taymiyya, for example, wrote Minhâj al-Sunnah al-Nabawiyyah fi Naqd Kalâm al-Shî́ah wa alQadariyyah (Ibn Taimiyyah n.d.) in which he delivers his argument against Shî'ah and Qadariyyah. Nevertheless, nowadays, the technology, that provides practicality, simplicity, and speed, transfers the disputes to a new medium, namely memes.

The most glaring disputes in the current contestation involve literalist (or textualist) against contextualist groups.

\section{Textualist vs Contextualist}

In a book Constructing a Religiously Ideal "Believer" and "Woman" in Islam: Neo-Traditional Salafi and Progressive Muslims' Method of Interpretation published in New York in 2011, Adis Duderija, as cited by Rahman, maps the tendency of the current Islamic thought based on the way the Qur'an and hadith are understood into two big groups: (1) a group that has the tendency to use textual approach, and (2) a group that has the tendency to employ contextual approach. The first group contains the Salafis or the new tradition Salafis (represented by Shaykh ibn Bâz, alAlbânî, al-Madkhalî, and so on), while the second group refer to progressive Muslims, such as Khalid Abou Fadl, Omid Safi, Farid Essack, and so on (Rahman 2012)

Abdullah Saeed defines textualist as those who 'argue for a strict following of the text and adopt a literalistic approach to the text.' For them, the Qur'an should become the guidance, despite the modern needs and contexts has changed and become different from it had been during the time of the Qur'an was being revealed. As a result, for them, the meaning of the text of the Qur'an (and the hadith as well) is clear and should be implemented at any time in any places. On the other hand, the contextualist, besides seeing the linguistic aspect of the Qur'anic text (and hadith), also emphasizes the importance of socio-historical context during 
the time of the revelation (past context) as well as the current context. The disputes between these two group are observed in memes on the internet.

Picture 5

(https://www.atsar.id)

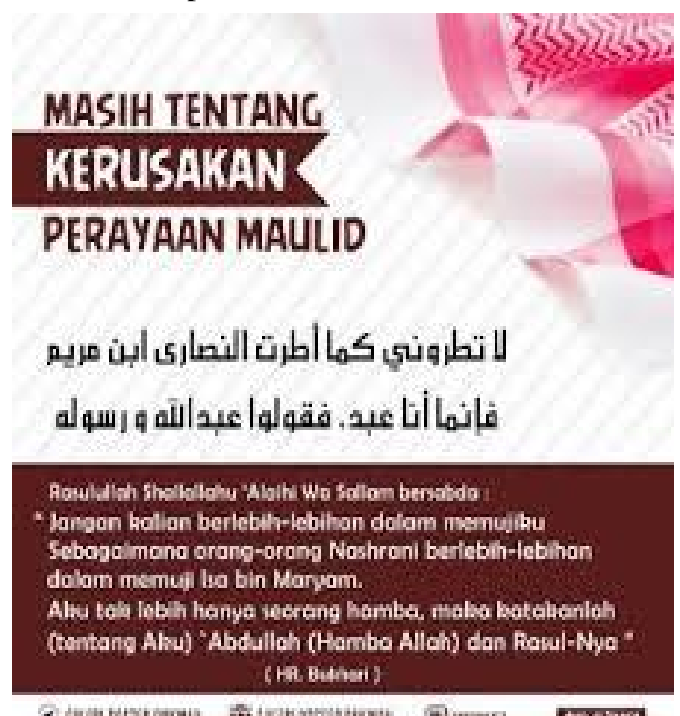

Picture 6

(https://www.pinterest.ca)

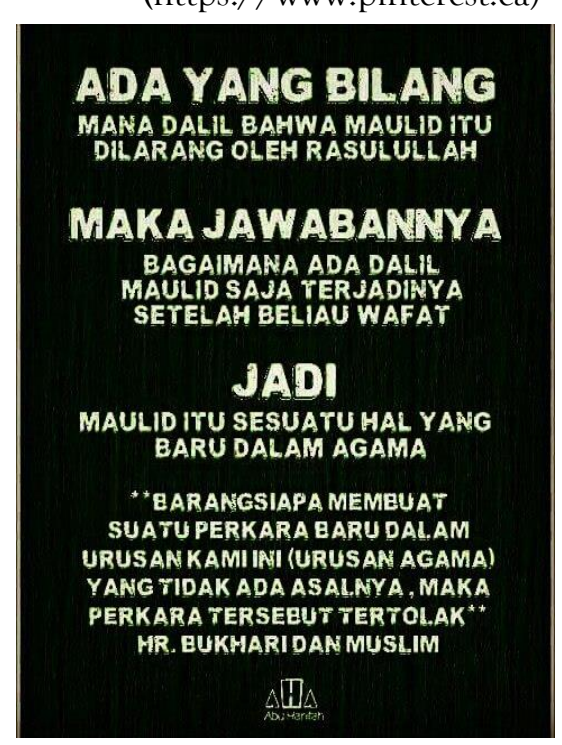

Picture 5 and 6 are memes from textualist group, in which they deliver their disagreement with contextualist in the context of the commemoration of the birth of the prophet Muhammad PBUH. They consider this commemoration negatively, and for that matter, should be annihilated. That is because they consider this commemoration as bid'ah, astray, and undermining religion. For them, every new matter in religion is bid 'ah, and every bid'ah is astray, and every astray conduct ends up in hell, accurately as represented by the text of the translation of a hadith provided in the meme picture six.

On the other hand, the contextualist views the hadith about bid 'ah should be understood in light of its history. Historically not all the bid 'ah were considered astray by the companions of the prophet. There is bid'ah hasanah (the virtuous bid'ah), there is also bid'ah dalâlah (the astray bid'ah). As long as those new matters are not immoral, the companions of the prophet considered them acceptable, let alone those that contain righteous deeds. Based on this rationale, this group delivers their 
argumentation against the textualist by creating memes, as in the following pictures.

Picture (7)

(http://kabarislamia.blogspot.com)

\section{KHALIFAH UMAR MEMBUNGKAM}

WAHABI YANG ANTI BID'AH HASANAH

Sayidina Umar

䊁 menggagas

shalat tarawih

pada seorang

imam, dan

beliau anggap sebagai bid'ah

paling

hasanah. (Al-

Hafizh Ibn

Hajar, Fath

al-Bari, juz 5,

hal. 448).

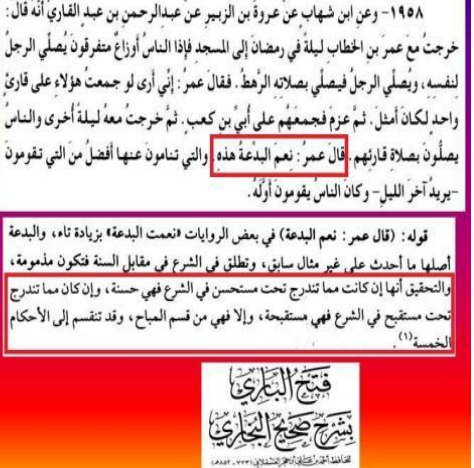

Picture (8)

(https://santri.net)

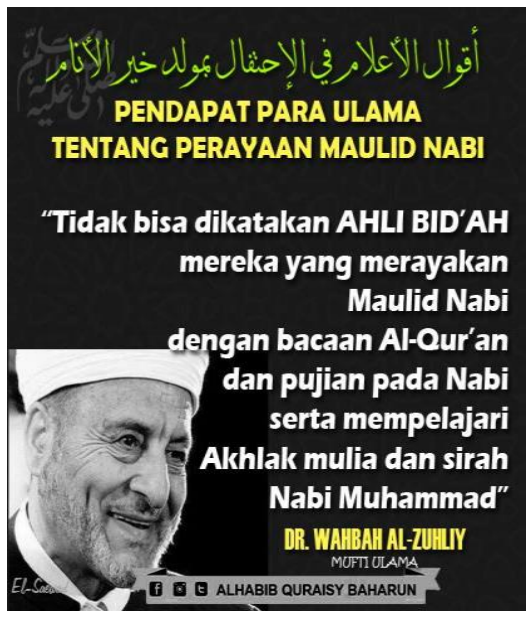

Picture 9

(https://image.slidesharecdn.com/maulidnabisaw-)

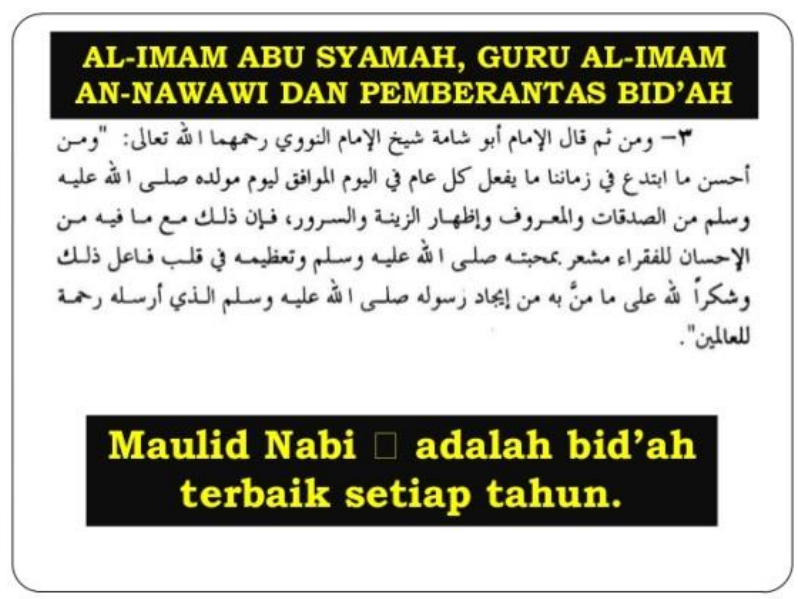

Ulul Albab Volume 20, No.2 Tahun 2019 
In the meme of picture 7, contextualist show a quote from Fath alBârî Sharh Sahîh al-Bukhârî that explains that bid 'ah is not as rigid as the textualist understands it and that the companions of the prophet recognized one type of bid'ah which is virtuous. The meme in the texts provides this message: "Sayyidina Umar menggagas shalat tarawih pada seorang imam, dan beliau menganggap sebagai bid'ah hasanah" (The Caliph Umar proposed to praytarawih to an imam, and he considered it as virtuous bid 'ah) (al-'Asqalânî 1993, 448). Despite providing a considerably long text, the meme does not provide the full translation of it, perhaps, because the creator is happy that the message is fully delivered with the Indonesian text provided.

In picture 8 and 9 , the message the memes want to deliver is that the renowned ulama, either the living ones to the classical ones with such a reputation such as Shaykh Abû Shâmah, the teacher of Imam al-Nawâwî alDimashqî, suggests that the commemoration of the birth of the prophet is not an astray bid'ah, but rather a virtuous bid'ah as practised by the companion 'Umar ibn al-Khațâb.

Memes of pictures 4, 5, and 6 represent the effort of the textualist to show their existence in the surface, before the public. They announce that they are the right one, have the right to exist to become the representation of Islam in the world. Their competing group could sink, lost, and disappear. From the perspective of Richard Dawkins' theory, memes from the textualist are the selfish or egoistic genes that always want to fight to win the battle against their competing group, the contextualist.

On the other hand, picture 7,8, and 9, show the effort of the contextualist to survive through their counter-argument against the textualist. All of those memes underline that the tradition of the commemoration of the birth of the prophet Muhammad practised by contextualist is by no means pervert and that this tradition also has historical justification from the practices of the companions of the prophet, the earlier to the current ulamas. This phenomenon support Dawkins' theory that memes also represent the contextualist who strives for survival amid the attack of the textualist. They do not want to disappear and be drowned by the new existences. In sum, each of the groups is in a constant battle to survive. In other words, this shows the principle of survival of the fittest, that only the strong one is able to survive. 
Nevertheless, this study found a preposition to complement Dawkins' theory. If Dawkins suggests that the weak memes would eventually vanish and drowned by the occurrence of new memes, this research suggests that the disappeared memes could in times re-emerge into the surface. In other words, it has the potential to resurrect. This typically happens to memes on religious issues that become regular disputes.

Memes on the commemoration of the birth of the prophet, for example, would disappear after the Rabî ' al-Awwal in the Hijri calendar. The disputes about the issue will typically cool down after one to three months after the Rabî al-Awwal, making memes in this topic rarely found in the social media. However, when Rabî̀ al-Awwal of the following year is approaching, the memes will re-emerge following the occurrence of the disputes about the issue.

This phenomenon is different from other cases of popular memes that work temporarily such as memes about the disputes between Ahok, the later Governor of Jakarta, and Haji Lulung, a member of Regional Representative Council of Jakarta from the PPP party (Juditha 2015), or memes about 2018 world cup; this kind of memes will eventually disappear very quickly after the relevant case or event passed away. On the other hand, memes about religious issues regularly came up, making possible the constant replication and imitation.

\section{Satire of Hadith memes and disputes of identity politics}

Of the interesting findings of this research is the emergence of identity politics hadith memes with satirical language. Pictures one to nine are memes that use the straightforward language. Unlike those memes, picture ten and eleven below use satirical language. Accordingly, the disputes of identity politics represented in hadith memes, besides straightforward language, also employ the satirical method. In KBBI, satire is defined as a particular style of expression in literature in order to deliver insinuation against a particular situation or an individual (KBBI 2019). Other literature defines satire as the combination of irony and sarcasm that is usually presented in humour. According to the Oxford Dictionary, the intention of satire is to expose or criticize an individual; accordingly, satire is about criticism (Wandilapalpa 2015).

Despite its humorous element, satire contains sharp and sometimes harsh messages. A sharp satire, known as well as sarcasm, has the potential to spark emotion and anger. According to Berger, satire is a technique used 
to create humour in a text, besides the techniques of definition, exposure, imitation and pretence, impersonation and recognition, and eccentricity. The technique of satire emphasizes ridicules and teases terrible habit of individuals, institutions, or other objects. This technique is usually bond to particular social and political circumstances and is aimed at social critics (Khairunnisa and Fahruddin 2013). Amongst the use of satire in hadith memes are the followings:

Picture 10

(https://www.facebook.com/abuaniy/)

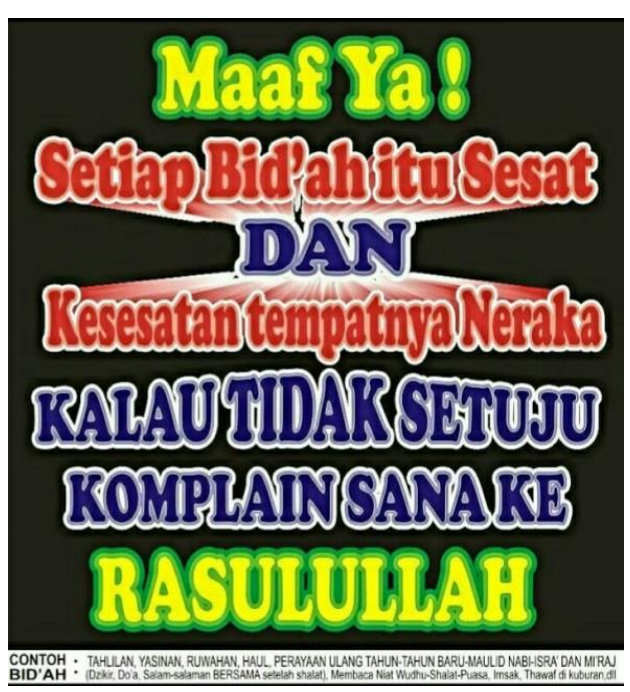

Picture 11

(https://sofyanruray.info/)

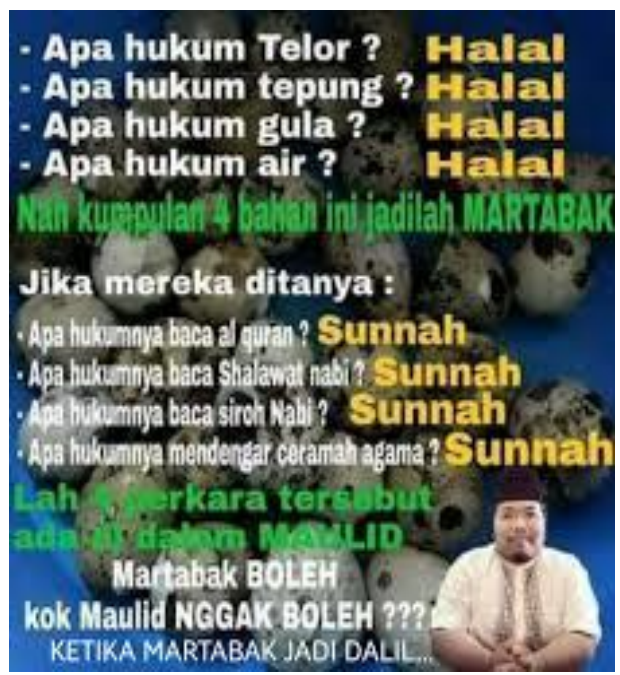

Picture 10 is quite apparent in its content, providing a sharp criticism against the contextualist group from the textualist. It says: "Maaf ya, setiap setiap bid 'ah itu sesat dan kesesatan itu tempatnya di neraka. Kalau tidak setuju, complain sana ke Rasulullah." (Sorry, every bid 'ah is astray, and every astray conduct would end up in hell. If you disagree, sent your complaint directly to the Prophet). In addition to this satire, in a white box at the down edge of the meme, it provides the conducts it considers bid'ah, namely yasinan, tahlilan, ruwahan, birthday party, new year party, commemoration of the birth of the Prophet, Isra ' Mi'râj, prayer, dhikr, shaking hands after prayer, reciting the intention of ablution, imsak, tawaf around the grave, etc. The expression of "kalau tidak 
setuju, komplain sana ke Rasulullah" is a harsh sarcasm because the disagreement in the issues is considered to go against the guidance of the Prophet Muhammad.

The meme displayed in picture 11 is an answer to that of picture 10. It contains a rebuttal argument against the textualist argumentation. This particular meme forms its message through a satirical question and answer technique. It says:

Apa hukumnya telor? Halal

Apa hukumnya tepung? Halal

Apa hukumnya gula? Halal.

Apa hukumnya air? Halal.

Nah, kumpulan 4 bahan ini jadilah martabak.

Jika mereka ditanya:

Apa hukumnya bacaan al-Qur'an? Sunnah.

Apa hukumnya bacaan Shalawat Nabi? Sunnah

Apa hukumnya baca sirah Nabi? Sunnah.

Apa hukumnya mendengarkan ceramah agama? Sunnah

Lah 4 perkara tersebut ada di dalam MAULID.

Martabak boleh.

Kok Maulid NGGAK BOLEH???

What is the legal status of an egg? Halal

What is the legal status of flour? Halal

What is the legal status of sugar? Halal

What is the legal status of water? Halal

Well, the combination of these four ingredients forms martabak.

If they are asked:

What is the legal status of reciting the Qur'an? Sunnah

What is the legal status of reciting șalawât upon the Prophet?

Sunnah

What is the legal status of reading the history of the Prophet?

Sunnah

What is the legal status of listening to religious preaching? Sunnah

Well, all of these are in MAULID.

Martabak is allowed,

Why would MAULID not?

The message written in picture 11 is sarcastic rhetoric delivered to the textualist, underlining that their rejection of the commemoration of the 
birth of the Prophet does not make sense. That is because they refer to one particular hadith about bid 'ah with a textual approach, and at the same time ignore other hadiths that say about the virtue of reciting the Qur'an, salawat, and so on. This is how the dispute on the issue continues to occur.

The polemics between the textualist and the contextualist groups is inseparable from the global political circumstances, especially with regards to the policy of Middle East countries where Islam came from initially. The emergence of the textualist group, who has the tendency to the strict reliance to the text of hadith and strong motivation to fight against what they consider bid'ah, is inseparable from the foreign policy of the Saudi Arabia Kingdom. The Saudi government gave ample funding for the scholarship (Bagi Arab Saudi, Mahasiswa Indonesia adalah Jalur bagi 'Soft Power' 2017).

Since the reformation era, 1,4 million Indonesian students every year have come to Saudi for their study (1,4 Juta Warga Indonesia Ke Arab Saudi Setiap Tahun, Beasiswa Untuk Mahasiswa Indonesia di Universitas King Khalid 2019). This figure is a significant increase compared to 1987 when there was only 904 Indonesian student who studied in the Saudi kingdom (Latif 2013, 495). In addition to free tuition-free, they are also provided with living cost, the round-trip flight from Indonesia to Saudi, as well as other benefits. After they have finished their study, these graduates came back to Indonesia becoming preachers, establishing educational institutions, even more, political party. In addition to that, the Saudi government has also sent books recording the thought of the Saudi figures to several institutions in Indonesia.

This network leads to the emergence of religious understanding that is not compatible with the socio-historical situation of Indonesia. The pictures four, five, and six, are the representation and examples of teachings spread out by the Saudi graduates. These memes are pretty much straightforward in their criticism against the commemoration of the birth of the Prophet that has been practised for a long time in Indonesia. According to them, this kind of tradition should be fought against. Not all Saudi graduates indeed involve in this movement; however, the public seems to have been widely exposed to their teaching that is widely disseminated through television and radio broadcasts. The figures such as Firanda Andirja, Khalid Basalamah, Reza Basalamah and so on are the central names whose though are distributed widely. Memes displayed in pictures 
four, five, and six are the replication of the teachings that come from this group.

Indonesian Muslims, who are accustomed to the commemoration of the birth of the Prophet Muhammad, cannot easily accept that another party vanishes all of a sudden what they have been practising for so long. For them, this tradition is not only about the difference of understanding but has become part of their life and their cultural identity that should be preserved and protected should other disturb it. If the textualist is striving for eliminating this practice in Indonesian society, the contextualist would protect it and continue to practice it.

\section{Hadith Memes in the Indonesian Election: Identity Politics for Power Contestation}

Although the identity politics occurred quite a long time ago, even before the independence of Indonesia (Habibi 2017), one of the most significant momenta of this politics in contemporary Indonesia is the 2017 gubernatorial election of Jakarta. The tension during the election was extremely high as the result of the use of religious texts in order to support one candidate and delegitimize others. The polemic has become the subject of scholarly inquiries from Abdullah, Khamdan and Wiharyani, Lestari, Sari, Fathoni and Yuwanto, Putra, Mahadika and Sardini, Fachrudin, and so on (Abdullah 2018; Khamdan and Wiharyani 2018; Lestari 2019; Sari 2016; Fathoni and Yuwanto 2019; Putra 2018; Mahadika and Sardini 2019; Fachrudin 2018; Kaltsum 2019; Prayogi 2019; Kiftiyah 2019).

When I type a keyword "Pilkada DKI politik indentitas" (Gubernatorial Election of DKI identity politics) in Google Scholars platform, only in the range of 0,11 second appear 1.310 writings about this topic (accessed November 29, 2019). This indicates the value of this moment that it attracts so much attention from scholars.

Ample memes containing identity politics are found as well during the 2017 Jakarta Gubernatorial Election. This is due to the doctrine, saying that Islam is a complete and self-sufficient religion, whose teaching touches upon every aspect in life, including politics. This view is not entirely wrong, because indeed there are Qur'anic texts that support this view. Nevertheless, if one approaches the text carelessly, it leads to the potential of carrying the text to justify the political interest of a particular party. In this context, religious texts become a tool to obtain power. 
In this context, the 2017 Jakarta Gubernatorial Election is the primary example. There were three candidate pairs in the election:

1. Agus Harimurti Yudhoyono and Silvi, proposed by the Democrat Party (Partai Demokrat) and the National Mandate Party (Partai Amanat Nasional)

2. Basuki Tjahaya Purnama (better known as Ahok) and Djarot Saiful Hidayat, proposed by PDIP, Golkar Party, PPP, PKB, Nasdem, and Hanura.

3. Anis Rashid Baswedan and Sandiaga Uno, proposed by PKS and Gerindra.

Since the beginning of the campaign period, religious texts emerges widely in society, trying to prevent them from voting for the candidate pair number 2, Ahok and Djarot, and allowing only either the pairs number one or three. The argument they provide is that one and three are the odd numbers, and Allah loves the odd numbers. The hadith they use is transmitted by al-Bukhârî and Muslim:

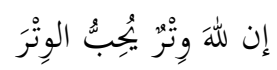

"Verily, Allah is witr, and he loves things witr (odd)" (al-Bukhârî 1993, 2354; Muslim 1992, 5).

This hadith is preached to mobilise people to not chose the candidate pair number two, Basuki Tjahaya Purnama (Ahok) and Djarot Saiful Hidayat, let alone that Ahok is non-Muslim. One of the memes in this context is the following:

Picture 12

(https://chirpstory.com/li/334438)

\section{AHMAD ALHABSYI @ustad_alhabsyi}
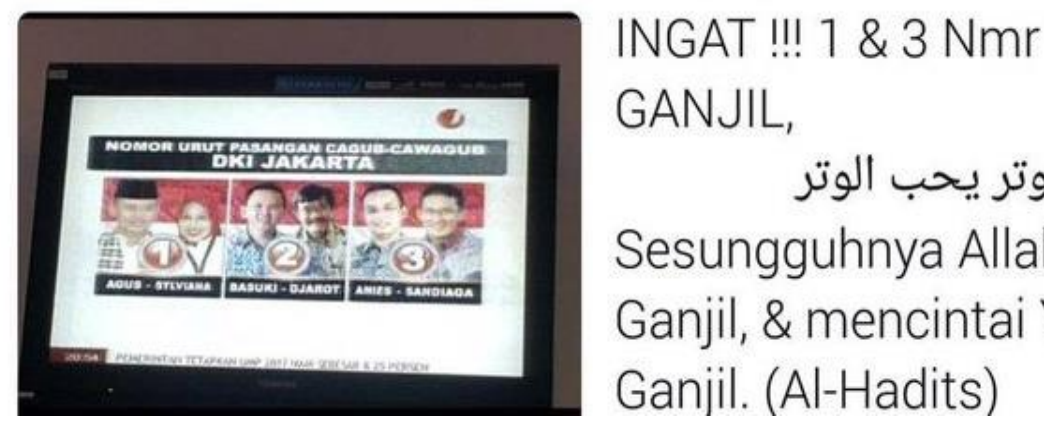

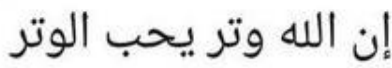

Sesungguhnya Allah itu Ganjil, \& mencintai Yg Ganjil. (Al-Hadits) 
After the gubernatorial election ends, the schedule for the election of the members of the house of representatives and the regional representative council comes. The mechanism of the election requires the candidates to apply through political parties instead of individuals as in the previous Jakarta Gubernatorial election. In this phase, the parties proposing candidate pairs number one and three turned out to be appointed in even numbers. Gerindra was appointed number two, PKS to number eight, PAN had number 12, and Democrat Party was appointed number fourteen. As a result, their competing parties deliver their counter-attack through a meme calling people not to vote odd numbers (See picture 13 below).

In the last two pictures (12 and 13), as shown by the memes provided earlier, it is pretty much apparent that the memes have become the representation of political parties in their campaign in order to convince voter so they can win the election using the prophetic hadith as a tool of the campaign. The contestation between hadith memes does not reflect only the effort of survival of a particular group, but also to obtain political power.

Picture 13

(https://twitter.com)

AHMAD ALHABSYI @ustad_alhabsyi

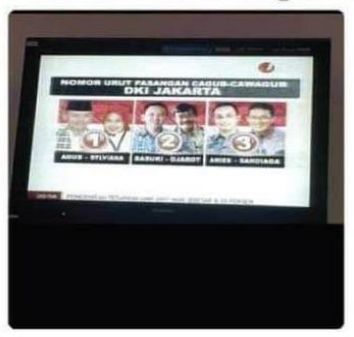

INGAT !!! $1 \& 3 \mathrm{Nmr}$

GANJIL, إن الله وتر يحب الوتر

Sesungguhnya Allah itu

Ganjil, \& mencintai Yg

Ganjil. (Al-Hadits)

Alhamdulillah, sesuai petunjuk ustadz, nanti pileg 2019 , tolong jangan pilih yang genap...

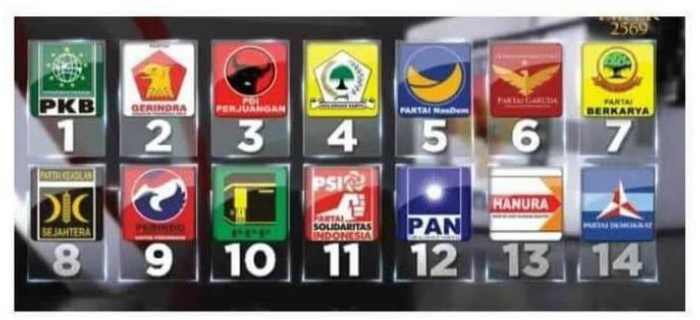

Karena sesungguhnya Allah cinta yang ganjil.... 
The above explanation indicates that the motive of the replication and the reproduction of the memes by a cultural system of a particular group is not as simple as a popular culture that tends to be trivial and frivolous. More than that, the meme is the smallest unit in a cultural system and identity politics of the specific groups that are bond to their interest. Each group are in a constant battle to survive their existence against other memes that occur from the other cultural and political system. This is pretty much different from the conclusion of Shao, that conveys three motives of the occurrence of memes: merely as self-expression, self-actualisation, and seeking attention (Kurniasih 2016).

More than self-expression and actualisation or the desire to be the spotlight, the meme is the powerful gene in a cultural system in a battle of identity politics, where the gene or the meme are egoistic; they are always ready to compete with other memes from another cultural system in order to maintain the existence of their respective groups.

\section{Conclusion}

This article suggests that in the Millenial era, hadith memes widely available on the internet are not merely artistic pictures that provide graphical beauty. More than that, those images are the genes that carry specific codes from a particular cultural system and messages from identity politics that emerge from the understanding and articulation of the attitude of their creators with regards to the hadith of the Prophet.

From this context, in general, the attitude of people on the prophetic tradition falls into two categories: the textualist and the contextualist. Because both groups have been in prolonged disputes and polemics, memes are the new medium where the Millenials articulate their ideas about the hadith. Memes that tend to be funny, humorous, and relaxing shift into an instrument of contestation between the groups that are striving to maintain their existence and undermining their competing group. The principle of survival of the fittest as known in the evolution theory in the biology, indicating that the strong one would remain exist, finds its articulation as well in the memes phenomena. Furthermore, hadith memes can also transform into genes carrying a political message whose end interest is a political power. 


\section{References}

"1,4 Juta Warga Indonesia Ke Arab Saudi Setiap Tahun, Beasiswa Untuk Mahasiswa Indonesia di Universitas King Khalid.” 2019. https://www.saudinesia.com/2019/02/27/14-juta-warga-indonesiake-arab-saudi-setiap-tahun-beasiswa-untuk-mahasiswa-indonesia-diuniversitas-king-khalid/ (November 28, 2019).

Abdullah, Assyari. 2018. "Membaca Komunikasi Politik Gerakan Aksi Bela Islam 212: Antara Politik Identitas dan Ijtihad Politik Alternatif." An-Nida': Jurnal Pemikiran Islam 41(2): 202-12.

Al Zidjaly, Najma. 2017. "Memes as Reasonably Hostile Laments: A Discourse Analysis of Political Dissent in Oman." Discourse $\mathcal{E}$ Society 28(6): 573-94.

DOI: https://doi.org/10.1177/0957926517721083

Anggalimea, Angeline. 2018. "Pembingkaian Sosok Basuki Tjahaja Purnama Dari Sudut Pandang Politik Identitas Pada Pilkada Dki Jakarta 2017 Dalam Eramuslim. Com Dan Tirto. Id." Undergraduate Thesis. Universitas Airlangga.

Alamsyah, Ryan. 2018. "Analisis Etnografi Virtual Meme Islami Di Instagram Memecomic. Islam.” Undergraduate thesis. Universitas Islam Negeri Syarif Hidayatullah Jakarta.

al-'Asqalânî, Ibn Hajar. 1993. Fatḥ al-Bârî Sharh Sahîh al-Bukhârî, vol. 5. Beirut: Dâr al-Fikr

"Bagi Arab Saudi, Mahasiswa Indonesia adalah Jalur bagi 'Soft Power'." 2017. https://www.voaindonesia.com/a/bagi-saudi-mahasiswaindonesia-jalur-bagi-soft-power-/3679847.html (November 28, 2019).

Bebić, Domagoj, and Marija Volarevic. 2018. "Do not mess with a meme: the use of viral content in communicating politics." Comunicación y Sociedad 31(3): 43-56.

DOI: $10.15581 / 003.31 .3 .43-56$

al-Bukhârî, Imâm al-Hâfize. 1993. Sahîh al-Bukhârî, vol. 5. n.p.: Dâr Ibn Kathîr. 
Fathoni, Rian and Yuwanto Yuwanto. 2019. "Perilaku Pemilih Masyarakat DKI Jakarta Pada Pemilihan Gubernur DKI Jakarta Tahun 2017.” Journal of Politic and Government Studies 8(01): 271-80.

Fachrudin, Achmad. 2018. "Rethinking Politik SARA di Pilkada DKI 2017." El Madani: Jurnal Pemikiran Dakwah dan Komunikasi Islam 1(1): 99-162.

Dawkins, Richard. 1976. The Selfish Gene. Oxford: Oxford University Press.

Ekstrand, Victoria Smith, and Derigan Silver. 2014. "Remixing, reposting, and reblogging: Digital media, theories of the image, and copyright law." Visual Communication Quarterly 21(2): 96-105.

DOI: https://doi.org/10.1080/15551393.2014.928155

Fatonah, Nurul, Sumarti Sumarti, and Bambang Riadi. 2017. "Permainan Bahasa Wacana Humor Akun Meme Comic Indonesia di Instagram serta Implikasinya." Jurnal Kata (Bahasa, Sastra, dan Pembelajarannya) 5(3): $1-12$.

Gervais, Daniel J., and Daniel Hyndman. 2012. "Cloud Control: Copyright, Global Memes and Privacy." Journal on Telecommunications and High Technology Law 10: 53.

Habibi, Muhammad. 2017. "Analisis Politik Identitas Di Indonesia." https://www.researchgate.net/publication/315338050 (December 1, 2019).

Haboddin, Muhtar. 2012. "Menguatnya Politik Identitas di Ranah Lokal." Jurnal Studi Pemerintahan 3(1): 116-34.

Harlow, Summer. 2013. "It Was a Facebook revolution": Exploring the Meme-Like Spread of Narratives During the Egyptian Protest." Revista de comunicación 12: 59-82.

Howard, Philip N., Aiden Duffy, Deen Freelon, M. M. Hussain, Will Mari, and Marwa Maziad. 2011. "Opening Closed Regimes: What Was the Role of Social Media During the Arab Spring?." https://papers.ssrn.com/sol3/papers.cfm?abstract_id=2595096 (November 26, 2019). 
Howard, Philip N., and Muzammil M. Hussain. 2013. Democracy's Fourth Wave?: Digital Media and the Arab Spring. Oxford: Oxford University Press.

Heiskanen, Benita. 2017. "Meme-ing Electoral Participation." European Journal of American Studies 12(2): 1-26.

Heikkilä, Niko. 2017. "Online Antagonism of the Alt-Right in the 2016 Election." European Journal of American Studies 12(2): 1-22.

Hukmi, Risalatul. n.d. "Meme' Theory: (Evolusi Kebudayaan menurut Richard Dawkins)." https://caridokumen.com/download/memetheory-evolusi-kebudayaan-menurut-richard-dawkins_5a44bf4bb7d7bc7b7a824808_pdf (August 13, 2018).

Hristova, Stefka. 2014. "Visual Memes as Neutralizers of Political Dissent." TripleC Journal for a Global Sustainable Information Society 12(1): 26576.

Ibn Taimiyyah. n.d. Minhaj al-Sunnah al-Nabawiyyah fî̀ Naqd Kalâm al-Shî‘ah wa al-Qadariyah Beirut: Dâr al-Kutub al-'Ilmiyyah.

Jarvis, Jason L. 2014. "Digital Image Politics: the Networked Rhetoric of Anonymous." Global Discourse 4 (2-3): 326-49.

DOI: https://doi.org/10.1080/23269995.2014.923633

Johnson, Shontavia Jackson. 2013. "Memetic Theory, Trademarks \& the Viral Meme Mark.” J. Marshall Rev. Intell. Prop. L. 13(1): 97-129.

Juditha, Christiany 2015. "Meme di Media Sosial: Analisis Semiotik Meme Haji Lulung." Jurnal Pekommas 18(2): 105-16.

Jurvetson, Steve. 2000. "What Exactly is Viral Marketing." Red Herring 78: 110-12. https://pdfs.semanticscholar.org/937d/5bf28040bdf9cbb 3c1a47da8853118eb49a7.pdf (November 24, 2019).

Kien, Grant. 2013. "Media Memes and Prosumerist Ethics: Notes Toward a Theoretical Examination of Memetic Audience Behavior." Cultural Studies? Critical Methodologies 13(6): 554-61.

DOI: https://doi.org/10.1177/1532708613503785

Khamdan, Muh., and Wiharyani Wiharyani. 2018. "Mobilisasi Politik Identitas dan Kontestasi Gerakan Fundamentalisme." Al-Tahrir: Journal of Islamic Thought 18(1): 193-218. 
DOI: https://doi.org/10.21154/altahrir.v18i1.1198

Kiftiyah, Anifatul. 2019. "Upaya Rekonsiliasi Politik Identitas Pasca Pelaksanaan Pemilu 2019 di Indonesia." Jurnal Analis Kebijakan 3(1): 63-75.

Kulkarni, Anushka. 2017. "Internet Meme and Political Discourse: A Study on the Impact of Internet Meme as a Tool in Communicating Political Satire." Journal of Content, Community $\mathcal{E}$ Communication 6(3): $13-17$.

Khairunnisa, Nurul Hikmah and Diding Fahrudin. 2013. "Analisis Tindak Tutur Dan Teknik Humor Dalam Wacana." http://www.lib.ui.ac.id/naskahringkas/2016-06/S53865Nurul\%20Hikmah\%20Khairunnisa (August 14, 2018).

Kurniasih, Nuning. 2016. "Pemilihan Gubernur DKI Jakarta 2017 dalam Meme: Sebuah Analisa Isi Terhadap Meme-meme di Dunia Maya." Proceeding Seminar Nasional dan Kebudayaan, Fakultas Ilmu Sosial dan Politik (FISIP) Universitas Padjadjaran, October 24-25, 2016. Bandung: Unpad Press, 279-84.

Latif, Yudi. 2013. Genealogi Intelegensia Pengetahuan $\mathcal{E}$ Kekuasaan Inteligensia Muslim Indonesia Abad XX. Jakarta: Kencana Pranada Media.

Lestari, Dina. 2019. "Pilkada DKI Jakarta 2017: Dinamika Politik Identitas di Indonesia." Simulacra: Jurnal Sosiologi 2(1): 31-37.

DOI: https://doi.org/10.21107/sml.v2i1.5519

Kaltsum, Lilik Ummi. 2019. "Politik dan Perubahan Paradigma Penafsiran Al-Qur'an dalam Proses Pilkada DKI Jakarta." At-Tibyan: Jurnal Ilmu Alqur'an dan Tafsir 4(1): 164-89.

DOI: https://doi.org/10.32505/tibyan.v4i1.786

Mahadika, Fariz, and Nur Hidayat Sardini. 2019. "Radikalisasi Isu Agama Dalam Pemilihan Gubernur dan Wakil Gubernur DKI Jakarta Tahun 2017." Journal of Politic and Government Studies 8(04): 131-40.

Moody-Ramirez, Mia, and Andrew B. Church. 2019. "Analysis of Facebook Meme Groups Used During the 2016 US Presidential Election.” Social Media+ Society 5(1).

DOI: https://doi.org/10.1177/2056305118808799 
Morimoto, Lori. 2018. "The 'Totoro Meme'and the Politics of Transfandom Pleasure." East Asian Journal of Popular Culture 4(1): 77-92.

DOI: https://doi.org/10.1386/eapc.4.1.77_1

Muslim, Imâm al-Hâfizẹ, 1992. Sahîh Muslim. Beirut: Dâr al-Kutub al'Ilmiyyah.

Murray, Noel, Ajay Manrai, and Lalita Manrai. 2014. "Memes, memetics and marketing." In The Routledge Companion to the Future of Marketing, ed. Luiz Moutinho, et.al. New York: Routledge: 331-47.

Muthohirin, Nafi. 2015. "Radikalisme Islam dan Pergerakannya di Media Sosial." Afkaruna: Indonesian Interdisciplinary Journal of Islamic Studies 11(2): 240-59.

Miski, Miski. 2017. "Fenomena Meme Hadis Celana Cingkrang Dalam Media Sosial." Jurnal Harmoni 16(2): 291-306.

DOI: https://doi.org/10.32488/harmoni.v16i2.7

Nindya, Ayu Pertiwi. 2019. "Implikatur Pada Meme Dakwah Islam Di Media Sosial Instagram (Kajian Pragmatik).” Undergraduate Thesis. Diponegoro University.

Owais, Rasha. 2011. "Arab Media During the Arab Spring in Egypt and Tunisia: Time For Change”. Middle East Media Educator 1(1): 9-13.

Putra, Yanuar Surya, 2016. "Theoritical Review: Teori Perbedaan Generasi." Jurnal Among Makarti 9(18): 123-34.

Putra, Alvian Dwiguntara. 2018. "Relasi Kekuasaan dan Pola Hubungan Politik Identitas Dalam Organisasi Kemasyarakatan.” Masters Thesis. Universitas Airlangga.

Prayogi, Irfan. 2019. "Populisme Islam dan Imajinasi Politik dalam Pilkada DKI Jakarta 2017.” Politeia: Jurnal Ilmu Politik 11(2): 31-43.

Rahman, Yusuf. 2012. "Penafsiran Tekstual dan Kontekstual terhadap alQur'an dan Hadith (Kajian terhadap Muslim Salafi dan Muslim Progresif).” Journal of Qur'an and Hadith Studies 1(2): 297-302. DOI: https://doi.org/10.1548/quhas.v1i2.1329

Ross, Andrew S., and Damian J. Rivers. 2017. "Digital cultures of political participation: Internet memes and the discursive delegitimization of 
the 2016 US Presidential candidates.” Discourse, Context $\mathcal{E}$ Media (16): $1-11$.

DOI: http://dx.doi.org/10.1016/j.dcm.2017.01.001

Rozaq, Muhammad Fathur. 2019. "Pengaruh Meme Terhadap Identitas Pemuda Muslim Nusantara: Telaah Respons Konten Instagram.” Analisis: Jurnal Studi Keislaman 19(1): 193-210

DOI: https://doi.org/10.24042/ajsk.v19i1.3030

Sari, Endang. 2016. "Kebangkitan Politik Identitas Islam Pada Arena Pemilihan Gubernur Jakarta." Kritis: Jurnal Ilmu Sosial dan Ilmu Politik Universitas Hasanuddin 1(1), 145-56.

Siregar, Ayu Lestari, Busmin Gurning, and Didik Santoso. 2018. "Stereotyped language about women on internet memes of meme comic Indonesia (A multimodal critical discourse analysis)." Jurnal Linguistik Terapan 15(2): 102-12.

Sudarsono, Sony Christian. 2017. "Diskreditisasi dan Resistansi Jomblo yang Terepresentasi dalam Wacana Meme Humor." Proceeding Seminar Tahunan Linguistik, Universitas Pendidikan Indonesia, August 10-11, 2017. Bandung: Prodi Lingistik SPs UPI, 399-403.

Sulthani, Muhammad Azhim. 2016. "Pengembangan Meme Comic Sebagai Media Pembelajaran Aqidah Akhlak Di Mts Mujahidin Mojokerto." Undergraduate Thesis. Universitas Islam Negeri Sunan Ampel Surabaya.

Untari, Dewi. 2017. "Gaya Bahasa Sindiran sebagai Kritik Sosial dalam Wacana Meme Berbahasa Jawa di Akun Instagram Dagelan_Jowo (Kajian Stilistika Pragmatik).” Masters Thesis. Universitas Sebelas Maret.

Wandilapalpa. 2015. "Meme Culture \& Komedi-Satire Politik: Kontestasi Pemilihan Presiden dalam Media Baru." Jurnal Ilmu Komunikasi 12(1): $1-18$

Williams, Russell. 2000. "The Business of Memes: Memetic Possibilities for Marketing and Management." Management Decision 38(4): 272-79.

DOI: https://doi.org/10.1108/00251740010371748

Wijayanto, Eko. 2013. "Memetika sebagai Studi Kebudayaan Berbasis Evolusi.” Jurnal Melintas 29(1): 42-55. 
DOI: https://doi.org/10.26593/mel.v29i1.264.42-55

Wu, Yufan, and Barry Ardley. 2007. "The Role of Branding: Applying Evolutionary Theory in Marketing." Systemica: Journal of the Dutch Systems Group 15: 147-56.

http://nuroneblog.blogspot.com/2017/02/sunnah-sunnah-rasulullah-sawmenjilati.html (August 13, 2018).

http://ikhlasmedia.blogspot.com/2016/11/adab-makan-dan-minum.html (November 28, 2019).

https://kbbi.kemdikbud.go.id/entri/meme (August 13, 2018).

https://kbbi.web.id/satire (August 13, 2018).

https://twitter.com (August 13, 2018).

https://www.toopics.com (November 28, 2018).

https://www.dutaislam.com (November 28, 2018).

https://www.atsar.id (November 28, 2018).

https://www.pinterest.ca (November 28, 2018).

http://kabarislamia.blogspot.com (November 28, 2018).

https://santri.net (November 28, 2018).

https://image.slidesharecdn.com/maulidnabisaw-, (November 28, 2018).

https://www.facebook.com/abuaniy/ (November 28, 2018).

https://sofyanruray.info/ (November 28, 2018).

https://www.picmog.com/user/islam.istiqomah/180449156/11459521421

71895557_180449156 (August 13, 2018). 